\title{
IN MEMORIAM TERÉZ LEHOCZKY
} (1929-2015)

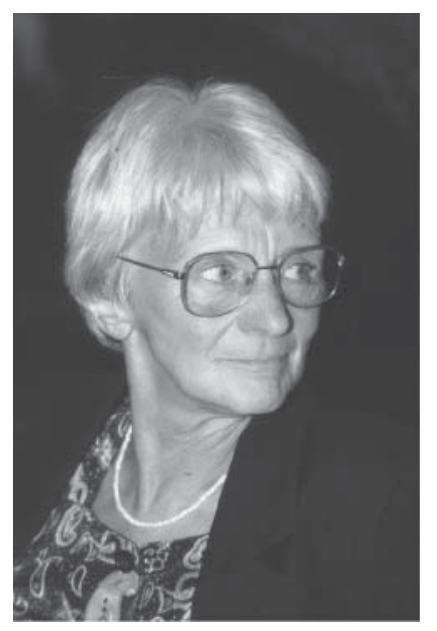

On 15th February 2015, Mrs. Teréz Lehoczky, member of the editorial office of Acta Alimentaria in the Central Food Research Institute and its successor institutes for over 30 years, passed away. She was librarian by profession, spoke German, English, and French. She worked as librarian at the Technical University of Budapest between 1952 and 1982, then joined the CFRI as member of the editorial staff of the Journal while Dr. Iván Varsányi was the co-ordinating editor. Her precision was just what was needed. She was responsible for administrating the Journal, for the correspondence with the authors, for checking the manuscripts for compliance with the guidelines, for inspecting the corrections, and for many other things occurring. She was precise and conscientious, sometimes even scrupulous. In the beginning there were one more colleague to work with, but when I took over the duty of co-ordinating editorship in 1998, she was the only one in the office. She had helped me through the initial difficulties, and I always could rely on her. When we started to handle the manuscripts (partly) electronically, she enrolled in a computer course and got familiar with it. She liked her work, also because - she used to say - it gave frame for her life. She stood down finally in 2013, however, for a year she still came twice a week to the editorial office to help us. Since the office in the last years was at the Department of Microbiology, she enjoyed the company also of young colleagues.

She was a highly intelligent woman, with good sense of humour. She liked reading and classical music. She loved sailing and skiing with her husband (who died in 2003) and family until the last years, and was happy with her family - her daughters, grandchildren, and greatgrandchildren, her brother and his family. She lived a full life. We lost a trustworthy colleague and I lost a good friend, too.

J. BECZNER 